\title{
Building Relational Understanding Through Hypothetical Learning Trajectory of Probability
}

\section{Fathur Rahmi1 ${ }^{*}$, Pinta Deniyanti Sampoerno ${ }^{2}$, Lukita Ambarwati ${ }^{3}$}

${ }^{1}$ Institut Agama Islam Negeri Bukittinggi, Agam, Indonesia

2,3 Universitas Negeri Jakarta, Jakarta, Indonesia

\begin{tabular}{l} 
A R T I C L E I N F O \\
\hline Article history: \\
2 December 2020 \\
Received in revised form \\
10 January 2021 \\
Accepted 25 January \\
2021 \\
Available online 25 \\
February 2021 \\
\\
\hline Kata Kunci: \\
Pendidikan Matematika \\
Realistik, Pemahaman \\
Relasional. \\
Keywords: \\
Realistic Mathematical \\
Education, Relational \\
Understanding
\end{tabular}

A B S T R A C T

Many researchers found that students had difficulty in understanding probability material. Students mostly focus on applying formulas to find solutions to problems without knowing what the concept is and why the formula works. This underlies the researcher to design probability learning as a hypothetical learning trajectory. The study aims to describe a series of learning activities designed to build relational understanding skills in probability material. This study uses a design research method consisting of three stages, namely preparation and design, teaching experiment, and retrospective analysis. Data collection techniques were carried out using a video recorder, documentation, and test questions. The data collected is in the form of qualitative data. The collected data is interpreted by peers, teachers, and supervisors to reduce the subjectivity of the researcher's point of view. All data that has been collected were analyzed retrospectively. The results of the research conducted showed that students experienced an increase and gave a good response in solving problems. Teachers are expected to use a learning design with a realistic mathematical approach because it helps students understand learning and apply their knowledge in everyday life.

\section{Introduction}

Many research studies have investigated how people understand with probability. Many of the things we do and the events that happen around us have consistent and completely predictable results (Bryant \& Nunes, 2012). Even though everyone understands about probability, there are still many people who have difficulty determining the exact chance of an event even in a fairly simple context and calculation (Bryant \& Nunes, 2012; Garfield \& Ahlgren, 1988). This can be seen in studies of psychological and teaching which have consistently documented that there is a poor understanding or misunderstanding of opportunity among different people (Fischbein \& Gazit, 1984; Kahneman \& Tversky, 1973; Konold, 1989; Konold et al., 1993; Nisbett et al., 1983). Many empirical studies since the 1970s have shown conclusively that this is far from true (Ang \& Shahrill, 2014; Garfield \& Ahlgren, 1988; Shaughnessy, 1977; Tversky \& Kahneman, 1974). Throughout adolescence, the problem of probability remains a serious challenge and only a small proportion of high school students are able to solve the problem of probability correctly and react adequately in situations of uncertainty (Heyvaert et al., 2018). Statistics and probability are some of the materials which include difficult subjects for students (Koparan,

Copyright (C) Universitas Pendidikan Ganesha. All rights reserved. 
2015). Students take on many unexpected difficult situations while solving probability problems with the intuitive nature of the concept of probability (Koparan \& Koparan, 2019). In addition, many people use non-standard strategies to reason probabilistically (Kahneman \& Tversky, 1972). The controversy surrounding the theory of probability presents a difficult question for educators: "What do we teach?" (Nilsson, 2003). Moreover, current practice instructions nationally have ignored this question simultaneously which introduces definitions of probability while ignoring differences and conflicts among their theoretical bases (Watkins et al., 2004). Often learning probability ignore the consequences of learning not understanding the meaning so that knowledge is not able to last long and students also only know how to memorize formulas. Students are not given the probability to express opinions and students are only given knowledge directly. This does not help students understand learning.

Understanding is one of the things that teachers must pay attention in learning. There are two types of mathematical understanding, namely instrumental understanding and relational understanding. Instrumental understanding refers to thoroughly studied knowledge and ideas that are completely isolated from one another (Skemp, 1976). Relational understanding, on the other hand, refers to the development of a meaningful network of concepts and procedures. Instrumental understanding means "to know how" and relational understanding means "to know not only how but also why". Relational thinking is centrally focused on solutions in which matter is connected to one another (Fischbein \& Gazit, 1984). As a result, certain ways of doing things (a practice) appear continuously in finding solutions (not given beforehand) and that can only be found by means of experiment (Decuypere \& Simons, 2016). Relational understanding is not information that must be 'be delivered' to students once, but gradually by reasoning and inference procedures that students can conquer logical interconnections between concepts (Karakonstantis \& Patronis, 2010). When students develop relational understanding, they acquire a way to move easily and skillfully (Jaber \& BouJaoude, 2012). In general, teachers' pay more attention to developing instrumental understanding. Instead of providing formulas, example questions, and questions that are almost similar to the example questions being taught. This makes students unable to remember the material for a long time. Therefore, it is necessary for teachers to design learning designs that help students build relational understanding.

Some countries have a tendency to emulate countries that excel in education in the hope that their students will perform like those countries. These countries tend to be followers of such an approach to education, because it has become a tradition in education to find better teaching. Through this process, often certain educational approaches, methods, models, theories or policies that have been developed in certain cultural settings are transferred and applied to other cultures (Andrews et al., 2014). One of the effects of globalization in the field of education is that policy makers and educators in a country will pay attention to the theories and learning approaches of countries that are successful in their learning and after that will try to adopt them. Through its development, the Indonesian mathematics curriculum has followed global trends in mathematics education. One of the approaches adopted in learning mathematics and which has been practiced in Indonesia is realistic mathematics education. RME inspires mathematics educators in many countries, including Indonesia. The RME approach is used by teachers in designing learning in order to achieve learning objectives, including building students' relational understanding of mathematics material, one of which is opportunity.

A problem is called "realistic" if the problem can be imagined or real in students' thinking (Wijaya, 2012). In addition, students should be given the opportunity to reinvent mathematics based on their own strategies (Yuberta et al., 2011). The philosophy underlying realistic mathematics education is that students develop mathematical understanding by working from contexts that make sense for students (Dickinson \& Houg, 2012). RME theory is basically a theory of knowledge construction, the idea is not to motivate students with the context of everyday life but to look for contexts that are based on real experiences for students and can be used as a starting point for progressive mathematics (Gravemeijer, 1999). One of the advantages of learning with the RME approach is that if students forget mathematical formulas, students can easily retrace the process when they first build a formula (Makonye, 2014). Thus, students consciously look for structures for mathematical symbols and terminology for concepts that have been taught. Mathematical procedures and knowledge are thus rediscovered in a meaningful way. One of the principles of RME or realistic mathematics education is that students make progress when they articulate their thoughts and when they can explain their actions. Students make little jumps to understanding by thinking about what they need to do and how students will try it and explain it to others (Dickinson \& Houg, 2012). So, the main concept in realistic mathematics education is the meaningfulness of the concept so that students are able to solve all problems related to their own language and remember them for a long time.

One of the things needed to reform mathematics education is a form of instructional design that supports instruction in helping students to develop their current way of thinking into a more 
sophisticated way of thinking mathematics (Gravemeijer, 1999). HLB is a way of explaining the important aspects of pedagogical thinking involved in teaching mathematics for understanding (M. Simon, 1995). In particular, it illustrates how mathematics educators such as teachers, researchers and curriculum developers oriented by a constructivist perspective and in particular the objectives of mathematics learning for students, can think about the design and use of mathematics assignments to promote conceptual learning (M. A. Simon \& Tzur, 2004). Interpretation of the learning trajectory hypothesis as a reform of mathematics education (Gravemeijer, 1999). Therefore, with the existence of a learning design, especially with reference to the hypothetical learning trajectory theory and a realistic mathematics approach, it is thought that it can help teachers in fostering student understanding, including relational understanding of learning material.

Given the difficulty of students understanding the meaning of opportunities based on several facts and theories conveyed by experts, this study will develop a learning design in the form of a learning trajectory hypothesis that supports students to understand the concept of opportunity. So, this research will describe a series of learning activities designed to bring students to build relational understanding skills in the opportunity material. Realistic mathematics education (RME) underlies the design of the activities. The research question is how to develop a learning design in the form of a learning trajectory hypothesis to help students build relational understanding in the material of empirical opportunities.

\section{Method}

Based on the questions and objectives of the study, the research method used was the design research method. Several steps in implementing design research namely design preparation, teaching experiments and retrospective analysis (Bakker, 2004; Gravemeijer \& Cobb, 2006). In the early stage, a hypothetical learning trajectory (HLT) will be designed which consists of teaching and learning activities, objectives for students and predictions of students' thinking processes during learning. A design and research instrument that has proven useful during the research design phase is called the HLT (Bakker, 2004). An HLT consists of objectives for learning, math tasks to be used to promote student learning, and hypotheses about student learning processes (M. A. Simon \& Tzur, 2004). So, the tool or instrument used was the HLT, while the analysis used was retrospective analysis by comparing the HLT with the results of the study. The main objective of this research is to design a series of activities and design instruments to evaluate the learning process to support students in building relational understanding. The following learning trajectory is used as shown in Table 1.

Tabel 1. Hypothetical Learning Trajectory

\begin{tabular}{|c|c|c|}
\hline Learning Context & Learning Activities & Learning Objectives \\
\hline $\begin{array}{l}\text { Indicators: Finding the concept of } \\
\text { empirical probability and } \\
\text { determining empirical probability. } \\
\text { Context: Spinner game. } \\
\text { Empirical probability is introduced } \\
\text { through spinner game trials. } \\
\text { The model of used is filling in } \\
\text { tables and graphs from the results } \\
\text { of the spinner game experiment. } \\
\text { The for model is the table and } \\
\text { graph used in understanding the } \\
\text { concept of probability. }\end{array}$ & 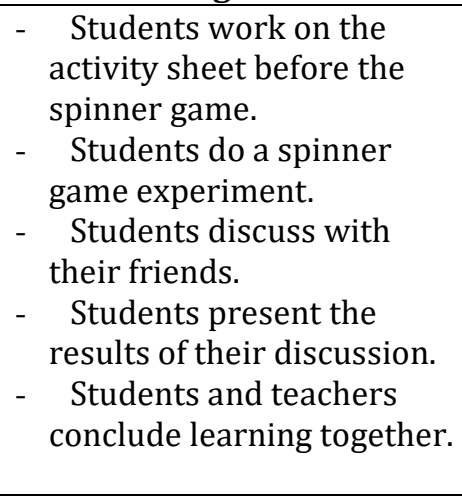 & 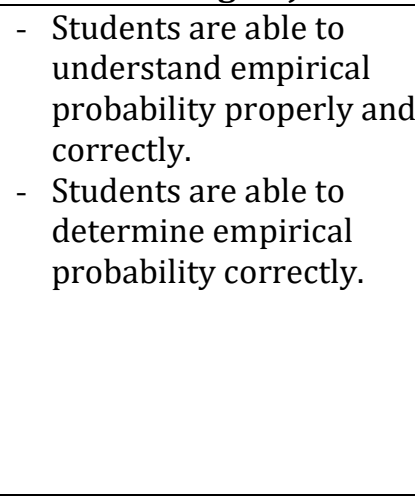 \\
\hline
\end{tabular}

The hypotheses in the HLT will be tested in a teaching experiment to improve the design. The teaching experiment aims to explore students' thinking during the learning process. The HLT design was tried out to see how it worked and to investigate students' thinking in solving problems. All data to be analyzed were collected during the teaching experiment process. The next stage, all the data that had been collected were analyzed in a retrospective analysis. Video recordings and student activity sheets will be used to investigate student learning processes. In addition, interviews were also conducted with students to get more information on their thinking processes. The data collected is in the form of qualitative data. The data collected were interpreted by peers, teachers and supervisors to reduce the subjectivity of the researcher's point of view. 


\section{Result and Discussion \\ Results}

In this activity the researcher will analyze and compare the assumptions made by the teacher on the hypothesis learning trajectory with the answers given by the students after working on student activity sheet with the RME-oriented context that the teacher has given. Before giving student activity sheet, the teacher has made assumptions about the whole learning process and also guesses about the possible answers that students will give after going through the learning process. Guesses that students might give in the conclusion of the problems given shown in Figure 1.

The activity that was carried out for the first time was group formation, before the teacher and the researcher discussed the groups to be formed in the discussion. This study has assumed that students already know about learning about the sample space and theoretical probability. Before starting the lesson the teacher repeats the material. Students discuss activity sheets with other students in the group. The spinner used in this study is a spinner that has two equal colors (assuming the theoretical probability has the same chance) as shown in Figure 2.

\section{Jawab: \\ Peluang empink adalah kemungkinan yang akan tejadi setelah melakukan percobaan \\ Perbedaan antara peluang empirik dan teoretik adalah: \\ Peluang teortik adalah perbandingan antara titik sampel dengan nang sampel. Sedangkan peluang empinik adalah perbandingan antara banyak kejadian dengan banyak percobaan.}

Figure 1. Teachers' Assumptions on the HLT

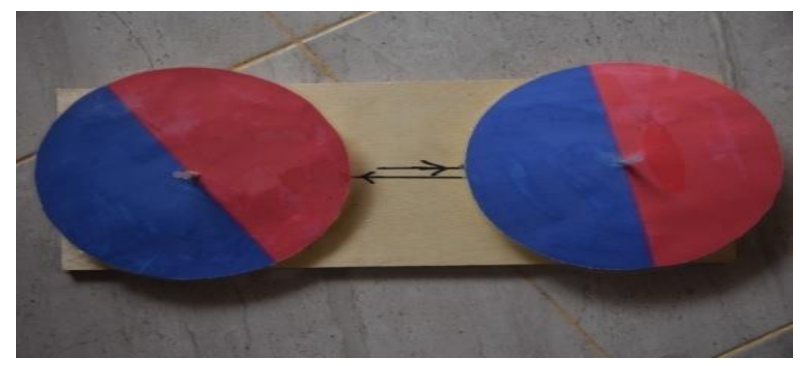

Figure 2. Spinner Used in Research

Before students start the spinner game, students first answer the problems in the activity sheet for prediction of the initial winner of the spinner game. Various kinds of student answers regarding predictions are related to what happens in students' daily lives.

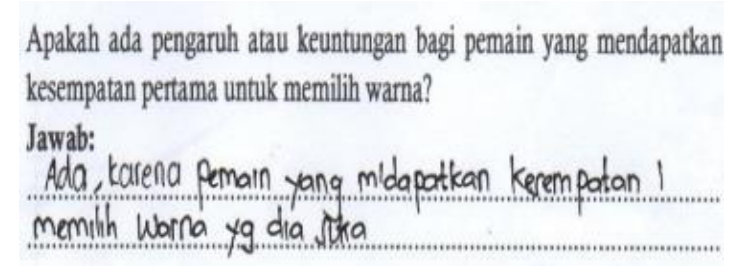

(a)

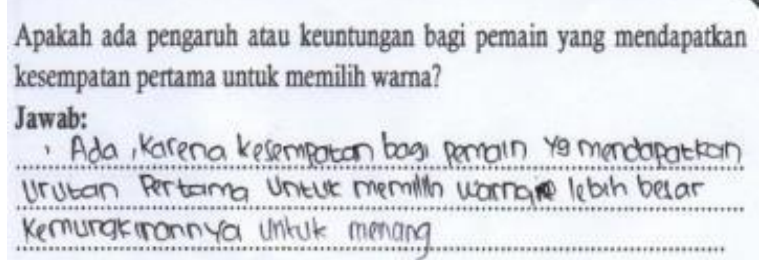

(b)

Figure 3. Students' Initial Predictions

Pay attention to the answers given in Figure (a) students are affected by their daily lives when giving answers as in Figure 3 (b) students also predict that the first voter will be lucky and it becomes an probability for the first voter to win.

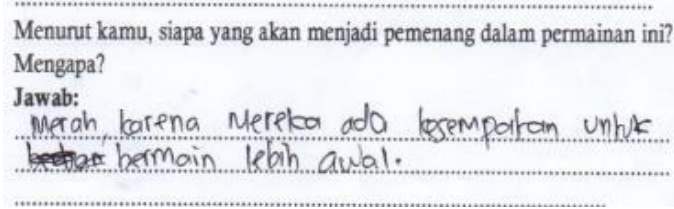

(a)

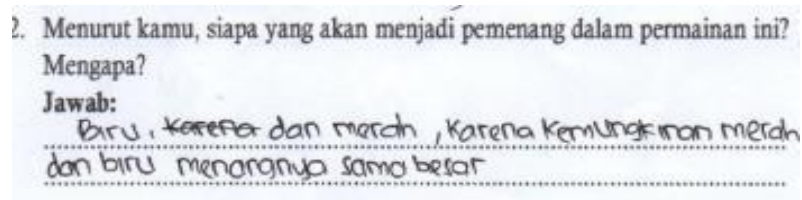

(b)

Figure 4. Student Predictions of Winners

Note in Figure 4(a) the students determine that the winner is based on who will play the first time, while in Figure 4(b) the students determine the prediction that the chances of winning are the same. Based on the answers given by students, it appears that the theory of probability is very much influenced by conditions in everyday life. Therefore, students must first understand the basic concept of probability by playing a spinner game. The spinner game begins by determining the student who will choose the spinner color for the first time, after which the two students continue with the game. When two students 
in their group play, the other students fill out the table and after that present it in a graphical form as shown in Figure 5.

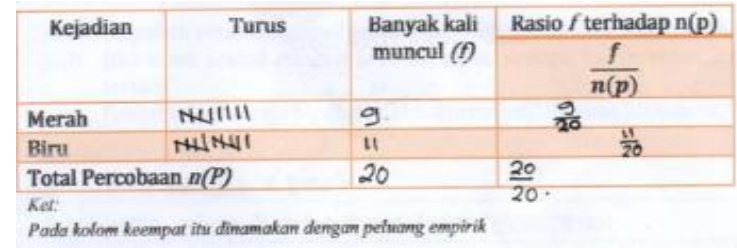

(a)

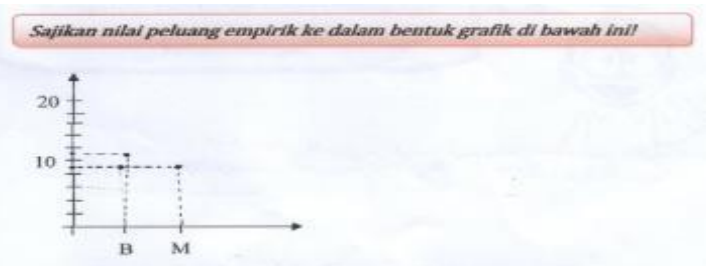

(b)

Figure 5. Results of Spinner Game

Note in Figure 5(a) students still remember previous learning, namely comparison through activities to complete tables. Students are also able to present data in graphical form in Figure 5(b). This indicates that students are still able to remember the previous material that has been discussed. Figure 5 is a model of bridging students' thoughts about empirical probability from the spinner game experiment process to become a for model as shown in Figure 6.

It can be seen in Figure 6 that students have been able to make definitions of empirical probability using their own language. Students are also able to distinguish between empirical and theoretical probability. Students are assisted by knowledge about the comparison and experimentation of spinner games that have been carried out with their group mates to begin to understand the concept of chance well. The presumption that HLB is in accordance with the results of the students' conclusions after going through the learning process. Students are able to find the concept of empirical probability correctly. This can be seen in the results of the student analysis of the predictions and experimental results as shown in Figure 7.

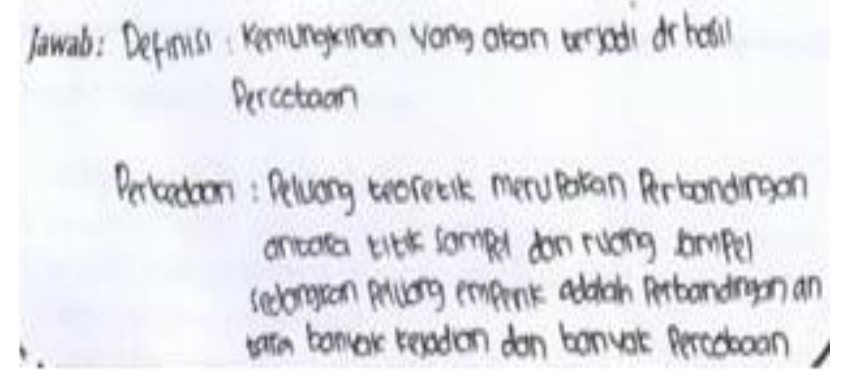

Figure 6. Conclusion of Student Discussion

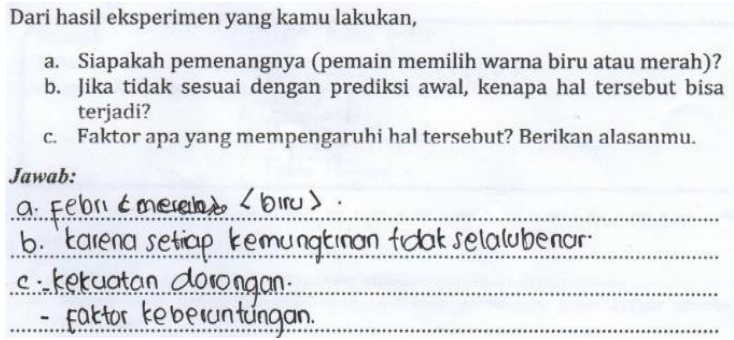

Figure 7. Student Analysis in Comparing Predictions and Experiments

Students seem to be able to analyze the concept of empirical probability correctly in relation to its application in life so that there are no more misunderstandings in understanding the concept of probability. Students also appear to be able to find their own definitions and concepts through discussion with their respective abilities. It can also be seen from the results of the discussion between the teacher and students when concluding learning as seen in the following transcript of the conversation:

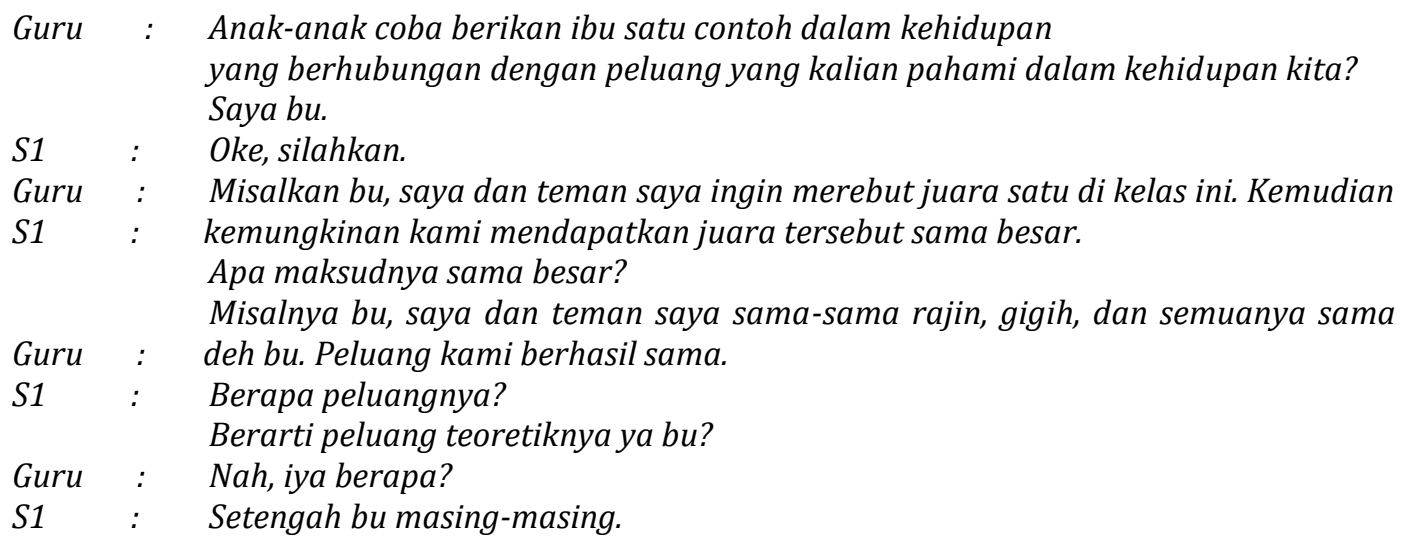




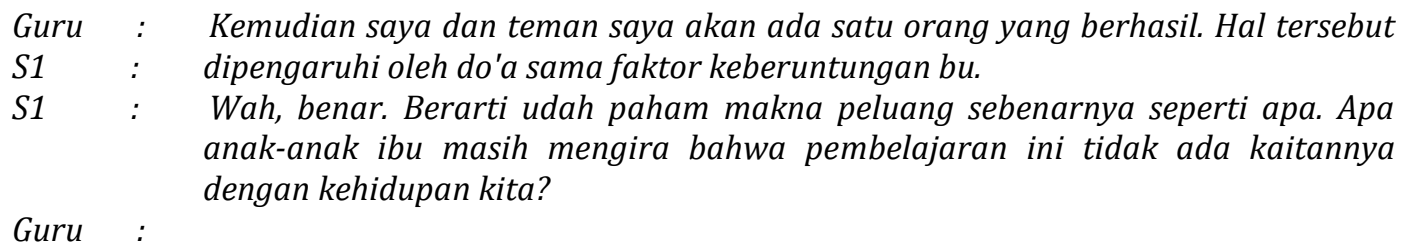

Students begin to be brave in expressing the ideas they have. Interactivity between teachers and students, students and other students can be seen in this study. This is very helpful for students in understanding the material given. Through this learning students build their own knowledge, this will help students in building relational understanding. The linkages between one material and another such as data presentation material, comparison and sample space are a concern when compiling learning designs. One of the things that becomes interesting is when students with weak abilities are able to answer problems given by the teacher when concluding learning, it can be seen from the discussion transcripts between students and teachers.

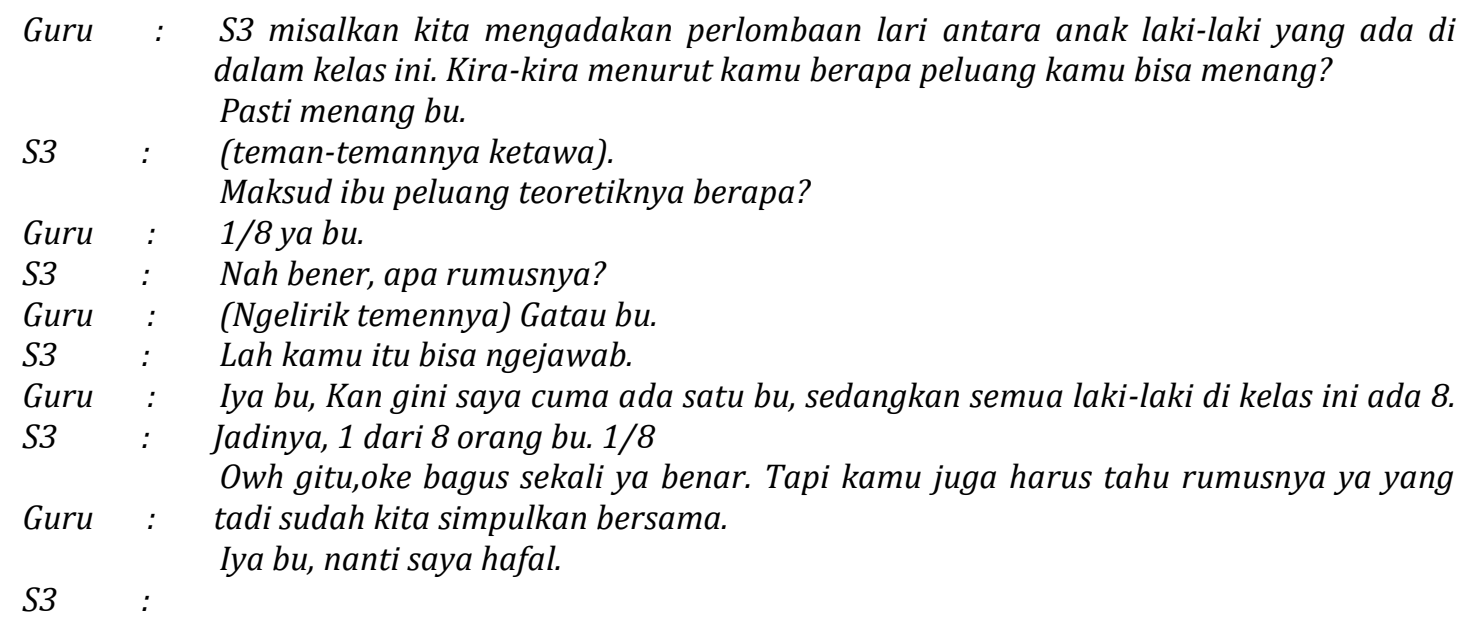

Based on the results of the conversation, it appears that students are able to remember the concept of probability and students also understand the problem without having to remember the formula. This indicates that the realistic mathematic education approach is good for application in learning and teachers must design learning to get good results. The hypothesis learning trajectory used also makes it easier for teachers to pay attention to each student activity.

\section{Discussion}

Understanding is one of the things that teachers must pay attention in learning. There are two types of mathematical understanding, namely instrumental understanding and relational understanding. Instrumental understanding refers to thoroughly studied knowledge and ideas that are completely isolated from one another (Skemp, 1976). Relational understanding, on the other hand, refers to the development of a meaningful network of concepts and procedures. Instrumental understanding means "to know how" and relational understanding means "to know not only how but also why". Relational thinking is centrally focused on solutions in which matter is connected to one another (Fischbein \& Gazit, 1984). As a result, certain ways of doing things (a practice) appear continuously in finding solutions (not given beforehand) and that can only be found by means of experiment (Decuypere \& Simons, 2016). Relational understanding is not information that must be 'be delivered' to students once, but gradually by reaso ning and inference procedures that students can conquer logical interconnections between concepts (Karakonstantis \& Patronis, 2010). When students develop relational understanding, they acquire a way to move easily and skillfully (Jaber \& BouJaoude, 2012). In general, teachers' pay more attention to developing instrumental understanding. Instead of providing formulas, example questions, and questions that are almost similar to the example questions being taught. This makes students unable to remember the material for a long time. Therefore, it is necessary for teachers to design learning designs that help students build relational understanding.

Some countries have a tendency to emulate countries that excel in education in the hope that their students will perform like those countries. These countries tend to be followers of such an approach to education, because it has become a tradition in education to find better teaching. Through this process, 
often certain educational approaches, methods, models, theories or policies that have been developed in certain cultural settings are transferred and applied to other cultures (Andrews et al., 2014). One of the effects of globalization in the field of education is that policy makers and educators in a country will pay attention to the theories and learning approaches of countries that are successful in their learning and after that will try to adopt them. Through its development, the Indonesian mathematics curriculum has followed global trends in mathematics education. One of the approaches adopted in learning mathematics and which has been practiced in Indonesia is realistic mathematics education. RME inspires mathematics educators in many countries, including Indonesia. The RME approach is used by teachers in designing learning in order to achieve learning objectives, including building students' relational understanding of mathematics material, one of which is opportunity.

A problem is called "realistic" if the problem can be imagined or real in students' thinking (Wijaya, 2012). In addition, students should be given the opportunity to reinvent mathematics based on their own strategies (Yuberta et al., 2011). The philosophy underlying realistic mathematics education is that students develop mathematical understanding by working from contexts that make sense for students (Dickinson \& Houg, 2012). RME theory is basically a theory of knowledge construction, the idea is not to motivate students with the context of everyday life but to look for contexts that are based on real experiences for students and can be used as a starting point for progressive mathematics (Gravemeijer, 1999). One of the advantages of learning with the RME approach is that if students forget mathematical formulas, students can easily retrace the process when they first build a formula (Makonye, 2014). Thus, students consciously look for structures for mathematical symbols and terminology for concepts that have been taught. Mathematical procedures and knowledge are thus rediscovered in a meaningful way. One of the principles of RME or realistic mathematics education is that students make progress when they articulate their thoughts and when they can explain their actions. Students make little jumps to understanding by thinking about what they need to do and how students will try it and explain it to others (Dickinson \& Houg, 2012). So, the main concept in realistic mathematics education is the meaningfulness of the concept so that students are able to solve all problems related to their own language and remember them for a long time.

\section{Conclusion}

This study answered research questions about how to develop a learning design in the form of a hypothesis learning trajectory to lead students to build relational understanding in the material of empirical probability. The learning design used can be carried out well. The results of student construction during learning play a very important role in developing students' relational understanding abilities because students can use their knowledge to build an understanding of a concept and be able to use it in solving a given problem. Teachers are expected to use a learning design with a realistic mathematical approach because it really helps students understand learning and apply their knowledge into everyday life.

\section{References}

Andrews, P., Ryve, A., Hemmi, K., \& Sayers, J. (2014). PISA, TIMSS and Finnish mathematics teaching: An enigma in search of an explanation. Educational Studies in Mathematics, 87(1), 7-26. https://doi.org/10.1007/s10649-014-9545-3.

Ang, L. H., \& Shahrill, M. (2014). Identifying students' specific misconceptions in learning probability. International Journal of Probability and Statistics, 3(2), 23-29. https://www.academia.edu/download/51830440/Identifying_Students_Specific_Misconcep2017 0216-29151-ly0s1w.pdf.

Bakker, A. (2004). Design Research in Statistics Education. On Symbolizing and Computer Tools. Wilco Press.

Bryant, P., \& Nunes, T. (2012). Children's Understanding of Probability a Literature Review (Full Report). Nuffield Foundation.

Decuypere, M., \& Simons, M. (2016). Relational thinking in education: Topology, sociomaterial studies, and figures. Pedagogy, Culture \& Society, 24(3), 371-386. https://doi.org/10.1080/14681366.2016.1166150.

Dickinson, P., \& Houg, S. (2012). Using Realistic Mathematics Education in UK Classrooms. Manchester Metropolitan University.

Fischbein, E., \& Gazit, A. (1984). Does the teaching of probability improve probabilistic intuitions? Educational Studies in Mathematics, 15(1), 1-24. https://doi.org/10.1007/BF00380436.

Garfield, J., \& Ahlgren, A. (1988). Difficulties in learning basic concepts in probability and statistics: Implications for research. Journal for Research in Mathematics Education, 19(1), 44-63. 
https://pubs.nctm.org/view/journals/jrme/19/1/article-p44.xml.

Gravemeijer, K. (1999). How Emergent Models May Foster the Constitution of Formal Mathematics. Mathematical Thinking and Learning, 1(2), 155-177. https://doi.org/10.1207/s15327833mtl0102_4.

Gravemeijer, K., \& Cobb, P. (2006). Design Research From The Learning Design Perspective. Educational Design Research. Routladge.

Heyvaert, M., Deleye, M., Saenen, L., Van Dooren, W., \& Onghena, P. (2018). How do high school students solve probability problems? A mixed methods study on probabilistic reasoning. International Journal of Research \& Method in Education, 41(2), 184-206. https://doi.org/10.1080/1743727X.2017.1279138.

Jaber, L. Z., \& BouJaoude, S. (2012). A macro-micro-symbolic teaching to promote relational understanding of chemical reactions. International Journal of Science Education, 34(7), 973-998. https://doi.org/10.1080/09500693.2011.569959.

Kahneman, D., \& Tversky, A. (1972). Subjective probability: A judgment of representativeness. Cognitive Psychology, 3(3), https://www.sciencedirect.com/science/article/pii/0010028572900163.

Kahneman, D., \& Tversky, A. (1973). On the psychology of prediction. Psychological Review, 80(4), 237245.

Karakonstantis, J., \& Patronis, T. (2010). Relational Understanding and Paths of Reasoning Through a Boolean Lattice Classification of Quadrilaterals. International Journal of Mathematical Education in Science and Technology, 41(3), 341-349. https://doi.org/10.1080/00207390903477434.

Konold, C. (1989). Informal conceptions of probability. Cognition and Instruction, 6(1), 59-98. https://doi.org/10.1207/s1532690xci0601_3.

Konold, C., Pollatsek, A., Well, A., Lohmeier, J., \& Lipson, A. (1993). Inconsistencies in students' reasoning about probability. Journal for Research in Mathematics Education, 24(5), 392-414. https://pubs.nctm.org/view/journals/jrme/24/5/article-p392.xml.

Koparan, T. (2015). Difficulties in learning and teaching statistics: teacher views. International Journal of Mathematical Education in Science and Technology, 46(1), 94-104. https://doi.org/10.1080/0020739X.2014.941425.

Koparan, T., \& Koparan, E. T. (2019). Empirical approaches to probability problems: An action research. $\begin{array}{lllll}\text { European Journal of Education } & \text { Studies, } & \text { 5(10), }\end{array}$ https://www.oapub.org/edu/index.php/ejes/article/view/2250.

Makonye, J. P. (2014). Teaching functions using a realistic mathematics education approach: A theoretical perspective. International Journal of Educational Sciences, 7(3), 653-662. https://doi.org/10.1080/09751122.2014.11890228.

Nilsson, P. (2003). Experimentation as a tool for discovering mathematical concepts of probability. Proceedings of the Third Conference of the European Society for Research in Mathematics Education.

Nisbett, R. E., Krantz, D. H., Jepson, C., \& Kunda, Z. (1983). The use of statistical heuristics in everyday inductive reasoning. Psychological Review, 90(4), 339. https://psycnet.apa.org/record/198403103-001.

Shaughnessy, J. M. (1977). Misconceptions of probability: An experiment with a small-group, activitybased, model building approach to introductory probability at the college level. Educational Studies in Mathematics, 8(3), 295-316. https://doi.org/10.1007/BF00385927.

Simon, M. (1995). Reconstructing Mathematics Pedagogy from a Construction Perspective. Jounal for Research in Mathematics Education, 26(1), 114-145.

Simon, M. A., \& Tzur, R. (2004). Explicating the role of mathematical tasks in conceptual learning: An elaboration of the hypothetical learning trajectory. Mathematical Thinking and Learning, 6(2), 91104. https://doi.org/10.1207/s15327833mtl0602_2.

Skemp, R. R. (1976). Relational understanding and instrumental understanding. Mathematics Teaching, 77(1), 20-26. http://www.davidtall.com/skemp/pdfs/instrumental-relational.pdf.

Tversky, A., \& Kahneman, D. (1974). Judgment under Uncertainty: Heuristics and Biases. Science, 185(4157), 1124-1131. https://science.sciencemag.org/content/185/4157/1124.abstract.

Watkins, A. E., Scheaffer, R. L., \& Cobb, G. W. (2004). Statistics in action: Understanding a World of Data. Key Curriculum Press.

Wijaya, A. (2012). Pendidikan Matematika Realistik. Suatu Alternatif Pendekatan Pembelajaran Matematika. Graha Ilmu.

Yuberta, K. R., Zulkardi, Z., Hartono, Y., \& van Galen, F. (2011). Developing Students Notion of Measurement Unit For Area. IndoMS. JME, 2(2), 173-184. https://repository.unsri.ac.id/6323/. 